\title{
Good Corporate Governance dan Kinerja Non Keuangan
}

\author{
Retno Wulandari ${ }^{1}$, Tumirin ${ }^{2 *}$, Suwandi ${ }^{3}$ \\ 1,2,3 Universitas Muhammadiyah Gresik, J1. Sumatra 101, Gresik, Indonesia
}

DOI: http://dx.doi.org/10.30587/jiatax.v1i2.1019

\begin{abstract}
Abstrak
The purpose of the research is to know the relationship between corporate governance and non financial corporate performance. The rating of corporate governance perception index (CGPI) is used by the Indonesian Intitute for Corporate Governance to meansure the corporate governance implementation, employee productivity as a business internal prespective measurement, and employee development corverage as a learning and growth perspective measurement. This research also uses control variable that are activa composition and growth opportunities. Using a multiple regression to test the hypothesis that corporate governance and non financial corporate performance are positively related. The analysis shows that there is a significant positive relationship between corporate governance index and employee productivity, but there is no significant positive between corporate governance and employee development coverage.
\end{abstract}

Jenis Kertas: Empiris

Key words : corporate governance, growth opportunities, employye productivity, employee development coverage

\section{Pengantar}

Rendahnya penerapan corporate governance yang ditandai dengan kurang transparannya pengelolaan perusahaan sehingga kontrol publik menjadi sangat lemah dan terkonsentrasinya pemegang saham besar pada beberapa perusahaan keluarga menyebabkan campur tangan pemegang saham mayoritas pada manajemen perusahaan sangat terasa dan menimbulkan konflik kepentingan yang sangat menyimpang dari norma-norma tata kelola perusahaan yang baik. Tindakan mementingkan diri sendiri yang dilakukan oleh pihak manajer perusahaan juga merupakan ciri utama lemahnya corporate governance. Jika para manajer perusahaan melakukan tindakan-tindakan yang mementingkan diri sendiri dengan mengabaikan kepentingan investor, maka akan mengakibatkan jatuhnya harapan para

\footnotetext{
${ }^{*}$ Penulis yang sesuai:

E-mail: tumirin@umg.ac.id

Afiliasi: Universitas Muhammadiyah Gresik
} 
investor tentang pengembalian (return) atas investasi yang mereka tanamkan (Johnson, Boone, Breach, \& Friedman, 2000).

Kebutuhan akan corporate governance yang berkualitas pada perusahaan memiliki kesempatan investasi yang tinggi dijelaskan dengan sudut pandang yang berbeda oleh (Durnev \& Kim, 2005) yang menjelaskan bahwa pada saat kesempatan investasi lebih menguntungkan, return atas investasi dari pemegang saham pengendali akan lebih besar dibandingkan dengan manfaat yang mereka dapat jika melakukan diskresi terhadap sumber daya perusahaan, sehingga akan menerapkan praktek corporate governance yang lebih berkualitas. Perusahaan-perusahaan di Asia yang mengalami penurunan kesempatan investasi, para pemegang saham pengendali melakukan diskresi/ekspropiasi terhadap sumber daya perusahaan pada periode krisis keuangan di Asia (Johnson et al., 2000). Hasil penelitian yang dilakukan (Durnev \& Kim, 2005) menunjukkan bahwa 27 negara-negara di Asia, Indonesia memiliki sistem hukum yang berkaitan dengan proteksi investor yang paling rendah. Rajan dan Zingales (1998) menyatakan bahwa para investor mengabaikan kelemahan-kelemahan dari perusahaanperusahaan di Asia Timur (East Asia) pada saat negara-negara tersebut pada kondisi perekonomian yang baik, akan tetapi secara cepat menarik investasi mereka pada saat krisis dimulai, karena para investor percaya bahwa negara tersebut tidak memiliki proteksi institusional yang memadai terhadap investasi yang mereka tanamkan.

Penelitian yang dilakukan di negara yang sedang berkembang masih sangat sedikit dilakukan. Black (2001) berargumen bahwa pengaruh praktek corporate governance terhadap nilai perusahaan akan lebih kuat di negara berkembang dibandingkan di negara maju. Hal tersebut dikarenakan oleh lebih bervariasinya praktek corporate governance di negara berkembang dibandingkan di negara maju. Dunev dan Kim (2002) memberikan bukti bahwa praktek corporate governance lebih bervariasi di negara yang memiliki lingkungan hukum yang lebih lemah. Beberapa penelitian menunjukkan tidak terdapat hubungan corporate governance dengan kinerja perusahaan, misalnya penelitian Bhagat dan Black (2002) tidak menemukan hubungan positif antara komposisi komisaris independen dengan kinerja perusahaan, dengan variabel kontrol termasuk karakteristik kepemilikan, dan size perusahaan. Pernyataan ini didukung oleh Gompers dkk (2003) menemukan hubungan negatif antara index corporate governance dengan kinerja perusahaan yang diukur dengan Tobin Q. Di lain pihak, berdasarkan penelitian Klapper dan Love (2002) menyatakan bahwa adanya hubungan positif antara corporate governance dengan nilai/kinerja perusahaan. Pernyataan ini didukung juga oleh penelitian Gompers dkk (2003) yang menemukan hubungan positif antara index corporate governance dengan kinerja perusahaan jangka panjang.

Sistem pengukuran kinerja baru dapat mempresentasikan aspek keuangan dan non keuangan. Konsep balanced scorecard sebagai measurement sistem yang mencoba untuk menyeimbangkan alat ukur lama yang hanya berdimensi pada profitabilitas dengan dimensi-dimensi yang baru seperti aspek kualitas yang memiliki elemen-elemen penyeimbang. Belum terdapatnya standarisasi indikator dari unit-unit produksi yang dapat diukur secara periodik, menyebabkan perusahaan mengalami kesulitan dalam memonitor pencapaian kinerjanya sehingga muncul ketidakefisienan dalam pemanfaatan sumber daya yang dimiliki maupun hasil atau pendapatan yang diperoleh. Pengimplementasian metode balanced scorecard salah satunya untuk dapat memperbaiki sistem pengukuran kinerja secara keseluruhan. Pengukuran berdasarkan konsep balanced scorecard (terdiri dari aspek keuangan dan non keuangan) sehingga perusahaan dapat melakukan perencanaan dan pengendalian terhadap tingkat pencapaian kinerjanya (Kaplan dan Norton, 1996).

Balanced Scorecard dapat menterjemahkan visi dan startegi perusahaan kedalam seperangkat ukuran yang menyeluruh yang memberi kerangka kerja bagi pengukuran dan sistem manajemen strategis (Kaplan dan Norton, 1996). Jika visi dan startegi dapat dinyatakan dalam bentuk yang strategis, ukuran-ukuran dan target yang jelas yang kemudian dikomunkasikan kepada setiap anggota perusahaan sehingga pengimplementasian visi dan strategi perusahaan dapat segera tercapai. Konsep Good Corporate Governance dan alat komunikasi Balanced Scorecard merupakan konsep yang sama-sama bertujuan meningkatkan nilai bagi perusahaan (internal maupun eksternal) untuk jangka waktu tertentu dalam bentuk keuangan maupun non keuangan.

Berdasarkan latar belakang permasalahan di atas, maka rumusan masalah yang akan diajukan adalah apakah terdapat hubungan positif antara penerapan corporate governance dengan kinerja perusahaan yang diukur dengan perspektif proses bisnis internal dan apakah terdapat hubungan positif antara penerapan corporate governance dengan kinerja perusahaan yang diukur dengan perspektif 
pembelajaran dan pertumbuhan. Kontribusi penelitian ini terletak pada pengukuran keinerja yang berbasis non financial.

\section{Telaah Literatur dan Pengembangan Hipotesis}

Perspektif hubungan keagenan merupakan dasar yang digunakan untuk memahami corporate governance. Hubungan keagenan adalah sebuah kontrak antara principal dan agen (Jensen and Meckling, 1976; dan Fama and Jansen, 1983). Inti dari hubungan keagenan adalah pemisahan antara kepemilikan (di pihak principal/investor) dan pengendalian (di pihak agent/manajer). Investor memiliki harapan bahwa manajer akan menghasilkan return dari uang yang mereka investasikan. Oleh karena itu kontrak yang baik antara investor dan manajer adalah kontrak yang mampu menjelaskan spesifikasispesifikasi apa sajakah yang harus dilakukan manajer dalam mengelola dana para investor, dan spesifikasi tentang pembagian return antara manajer dengan investor. Namun demikian, investor diharuskan untuk memberikan hak pengendalian residual (residual control right) kepada manajer, yaitu hak untuk membuat keputusan dalam kondisi-kondisi tertentu yang sebelumnya belum terlihat dikontrak.

Teori keagenan berusaha untuk menjawab masalah keagenan yang terjadi jika pihak-pihak yang saling bekerja sama memiliki tujuan dan pembagian kerja yang berbeda. Secara khusus teori keagenan membahas tentang hubungan keagenan, dimana suatu pihak tertentu (principal) mendelegasikan pekerjaan kepada pihak lain (agent), yang melakukan pekerjaan. Dengan adanya pemisahan peran antara pemegang saham sebagai prinsipal dengan manajer sebagai agennya, maka manajer pada akhirnya akan memiliki hak pengendalian yang signifikan dalam hal bagaimana mereka mengalokasikan dana investor (Jensen \& Meckling, 1976).

Oleh karena itu unit analisis dalam teori keagenan adalah kontrak yang melandasi hubungan antara prinsipal dan agen, maka fokus dari teori ini adalah pada penentuan kontrak yang paling efisien yang mendasari hubungan antara prinsipal dan agen. Teori keagenan dilandasi oleh beberapa asumsi (Eisenhardt, 1989). Asumsi-asumsi tersebut dibedakan menjadi tiga jenis, yaitu asumsi tentang sifat manusia, asumsi keorganisasian dan asumsi informasi. Asumsi sifat manusia menekankan bahwa manusia memiliki sifat mementingkan diri sendiri (self-interest), memiliki keterbatasan rasionalitas (bounded rationality), dan tidak menyukai resiko (risk oversion). Asumsi keorganisasian adalah adanya konflik antar anggota organisasi, efisiensi sebagai kriteria efektivitas, dan adanya asimetri informasi antara prinsipal dan agen. Asumsi informasi adalah bahwa informasi sebagai barang komoditi yang bisa diperjual belikan.

Jansen dan Mecking (1976) juga menunjukkan adanya tiga unsur tambahan yang dapat membatasi perilaku menyimpang yang dilakukan oleh agen. Unsur-unsur tersebut adalah bekerjanya pasar tenaga manajerial, bekerjanya pasar modal dan unsur bekerjanya pasar bagi keinginan menguasai dan memiliki/mendominasi kepemilikan perusahaan (market for corporate control). Bekerjanya pasar modal secara efisien bisa menjadi cermin kinerja manajer dari harga saham perusahaannya. Bekerjanya market for corporate control bisa menghambat tindakan menguntungkan diri pengelola sendiri dalam hal menghentikan pengelola dari jabatanya jika perusahaan yang dikelolanya mempunyai kinerja rendah yang memungkinkan pemegang saham baru menggantinya dengan pengelola lain setelah perusahaan diambil alih.

Teori agensi (agency theory), atau yang juga biasa disebut contracting theory, merupakan salah satu aliran riset akuntansi terpenting dewasa ini. Teori keagenan (agency theory) berusaha menjelaskan tentang penentuan kontrak yang paling efisien yang bisa membatasi konflik/masalah keagenan (Jensen dan Meckling, 1976). Asumsi yang mendasarinya adalah bahwa individu bertindak demi kepentingannya sendiri bertentangan dengan stewardship theory dimana agency theory memandang bahwa individu dalam hal ini manajemen tidak dapat dipercaya untuk bertindak dengan sebaik-baiknya bagi kepentingan publik pada umumnya maupun shareholders pada khususnya. Asumsi penting lainnya menyebutkan bahwa perusahaan merupakan tempat (locus) atau titik pertemuan (intersection point) bagi berbagai jenis hubungan kontraktual yang terjadi diantara manajemen, pemilik, kreditor, dan pemerintah.

Dalam perkembangannya, agency theory mendapat respon lebih luas karena dipandang lebih mencerminkan kenyataan. Berbagai pemikiran mengenai corporate governance berkembang dan bertumpuh pada agency theory di mana pengelolaan perusahaan harus diawasi dan dikendalikan untuk 
memastikan bahwa pengelolaan dilakukan dengan penuh kepatuhan kepada berbagai peraturan dan ketentuan yang berlaku. Durnev dan Kim (2003) menyatakan bahwa lemahnya sistem hukum/proteksi terhadap investor, maka konsentrasi kepemilikan menjadi alat yang lebih penting untuk mengatasi masalah-masalah keagenan. Upaya ini menimbulkan apa yang disebut agency cost, yang menurut teori ini harus dikeluarkan sedemikian rupa sehingga biaya untuk mengurangi kerugian yang timbul karena ketidakpatuhan setara dengan peningkatan biaya.

Implementasi corporate governance bervariasi dikarenakan adanya variasi manfaat pengendalian yang diberikan dan biaya yang ditimbulkan bagi manajer dan pemegang saham perusahaan (Gillian dkk, 2003). Agency cost ini mencakup biaya untuk pengawasan oleh pemegang saham, biaya dikeluarkan oleh manajemen untuk menghasilkan laporan yang transparan, termasuk biaya audit yang independen dan pengendalian internal, serta biaya yang disebabkan karena menurunnya nilai kepemilikan pemegang saham sebagai bentuk 'bonding expenditures' yang diberikan kepada manajemen dalam bentuk opsi dan berbagai manfaat untuk tujuan menyelaraskan kepentingan manajemen dengan pemegang saham. Oleh karena itu, teori agensi berfokus pada kos-kos pemantauan dan penyelenggaraan hubungan antara berbagai pihak.

Pengukuran kinerja merupakan salah satu faktor yang sangat penting bagi perusahaan yang antara lain dapat digunakan untuk menilai keberhasilan perusahaan dan juga dapat digunakan sebagai dasar untuk menyusun sistem imbalan dalam perusahaan. Selama ini pengukuran atau penilaian kinerja secara tradisional hanya menitikberatkan pada sisi keuangan saja. Perusahaan membutuhkan alat komunikasi yang dapat digunakan untuk mengkomunikasikan rencana-rencana strategis kepada semua anggota perusahaan. Alat komunikasi yang bisa digunakan oleh perusahaan adalah Balanced Scorecard (Malina dan Selto, 2001).

Menurut Hansen dan Mowen (1999;375) penekanan yang berlebihan pada pengukuran ini dapat menyebabkan prilaku disfungsional yang disebut myopia atau milking the firm. Prilaku myopia (myopic behivor) terjadi apabila manajemen mengambil tindakan yang memperbaiki kinerja anggaran dalam jangka pendek tetapi membahayakan perusahaan dalam jangka panjang. Balanced Scorecard sebagai suatu sistem pengukuran kinerja dapat digunakan sebagai alat pengendalian, analisa dan merevisi startegi perusahaan (Campbell dkk, 2002).

Untuk itu muncul pengukuran yang sifatnya non keuangan, misalnya dari sudut waktu, kepuasan pelanggang, kualitas dan lain-lain. Balanced scorecard merupakan sistem pengukuran kinerja yang mengkombinasikan penilaian keuangan dengan penilaian non keuangan yang terkait dengan kepuasan pelanggan. Dengan menggunakan konsep balanced scorecard perusahaan dapat mengukur kinerja yang seimbang antara keuangan dan non keuangan, ukuran hasil (lag measure) dan ukuran pemicu (lead measure), pengukuran jangka panjang (long term) dan pengukuran jangka pendenk (short term) serta pengukuran internal dan eksternal.

Keuntungan dari metode pengukuran kinerja dengan pendekatan balanced scorecard seperti yang diperkenalkan Kaplan dan Norton (1996) adalah karena pendekatan ini berusaha menterjemahkan visi dan strategi suatu organisasi kedalam tujuan (objective) dan pengukuran kinerja (performance measure). Pengukuran kinerja pada perusahaan publik dapat meningkatkan pertanggungjawaban dan memperbaiki proses pengambilan keputusan (Ittner dan Larcker, 1998). Tujuan dan pengukuran ini dibuat strukturnya kedalam empat prespektif, yaitu prespektif keuangan, prespektif pelanggan, prespektif proses bisnis internal dan prespektif proses belajar dan berkembang.

Secara umum, terdapat empat perspektif kinerja bisnis yang diukur dengan balanced scorecard, yaitu: Perspektif Keuangan (Financial Perspective). Balanced Scorecard memakai perspektif keuangan sebagai perspektif yang terjadi akibat dari perspektif yang lain (pelanggan, proses bisnis internal dan pembelajaran \& pertumbuhan)

Kaplan dan Norton (1996) mengidentifikasi tiga tahapan dari siklus kehidupan bisnis, yaitu : a) Bertumbuh (Growth), perusahaan mengarahkan segala sumber daya untuk membangun dan memperluas berbagai prasarana sehingga investasi yang dilakukan oleh perusahaan sangat tinggi. Maka tolok ukur yang dapat digunakan adalah tingkat pertumbuhan pendapatan atau penjualan; b) Bertahan (Sustain), investasi tetap dilakukan namun lebih ditujukan untuk mengatasi kemampatan dalam proses produksi dengan cara misalnya meningkatkan kapasitas produksi dan menyempurnakan proses produksi. Tolok ukur yang digunakan dalam tahap ini adalah besarnya pendapatan operasional (operating income), besarnya laba kotor (gross margin), tingkat pengembalian investasi (return on invesment), dan besarnya nilai tambah ekonomis (economic value added); c) Menuai (Harvest), produk 
yang dihasilkan telah mencapai titik jenuh, sehingga investasi dalam skala besar sudah tidak diperlukan lagi, maka tolok ukur yang dapat digunakan adalah besarnya arus kas masuk dari kegiatan operasi perusahaan.

Perspektif Pelanggan (Customer Perspective), manajemen perusahaan mengidentifikasikan dan mendefinisikan pelanggan dan segmen pasarnya di mana segmen pasar tersebut akan bersaing dan pengukuran dari unit bisnis tersebut pada segmen pasar yang ditujunya. Perspektif ini memiliki beberapa pengukuran utama dari outcome yang sukses dengan formulasi dan penerapan strategi yang baik. Sasaran strategis dari perspektif pelanggan ini adalah Firm equity, di antaranya adalah meningkatnya kepercayaan pelanggan atas produk dan jasa yang ditawarkan perusahaan, kecepatan layanan yang diberikan dan kualitas hubungan perusahaan dengan pelanggannya.

Kinerja ini dianggap penting dewasa ini mengingat semakin ketatnya kompetisi mempertahankan para pelanggan lama dan merebut para pelanggan baru. Sebelum tolok ukur pelanggan ditetapkan, Kaplan dan Norton (1996) menyarankan agar perusahaan menetapkan terlebih dahulu menentukan segmen pasar yang akan menjadi target serta mengidentifikasikan keinginan dan kebutuhan para pelanggan yang berada dalam segmen tersebut, sehingga tolok ukurnya lebih terfokus.

Perspektif Proses Bisnis Internal (Process Business Internal Perspective), yang menjadi fokus adalah proses internal dari manajemen perusahaan yang harus dilakukan. Proses ini memungkinkan unit bisnis tersebut untuk: memberikan proposisi nilai yang akan menarik dan mempertahankan pelanggan pada segmen pasar yang dituju, memuaskan ekspektasi pemegang saham pada ROI yang sangat baik.

Perspektif proses bisnis internal memberikan dua perbedaan fundamental antara pendekatan tradisional dan Balanced Scorecard untuk pengukuran kinerja. Pendekatan tradisional bertujuan untuk memantau dan meningkatkan proses bisnis. Sementara pendekatan Balanced Scorecard akan selalu mengidentifikasi keseluruhan proses yang baru dimana suatu organisasi harus memenuhi tujuan keuangan dan pelanggannya. Sasaran strategik dari perspektif proses bisnis ini adalah organizational capital seperti meningkatnya kualitas proses layanan kepada pelanggan, komputerisasi proses layanan kepada pelanggan, dan penerapan insfrastruktur teknologi yang memudahkan pelayanan kepada pelanggan.

Perspektif Pembelajaran dan Pertumbuhan (Learning and Growth Perspective), Perspektif pembelajaran dan pertumbuhan dari Balanced Scorecard ini mengidentifikasi infrastruktur yang harus dibangun perusahaan untuk membentuk pertumbuhan jangka panjang dan peningkatannya. Bisnis tidak dapat memenuhi kebutuhan jangka panjang pada pelanggan dan proses internal menggunakan teknologi dan kapabilitas sekarang. Untuk itu mereka harus terus menerus meningkatkan kapabilitas mereka dalam memberikan nilai pada pelanggan dan pemegang saham. Sasaran strategik dari perspektif pembelajaran dan pertumbuhan adalah Human Capital seperti meningkatnya kompetensi dan komitmen dari staf perusahaan.

Setiap tujuan dan ukuran dari setiap perspektif merupakan suatu hubungan sebab akibat yang dapat membantu memprediksi tujuan financial yang akan tercapai, dan dapat menciptakan proses pembelajaran, motivasi dan komunikasi yang aktif (Malina dan Salto, 2004)

Komitmen dalam perusahaan dapat tercipta apabila individu dalam perusahaan sadar akan hak dan kewajiban dalam perusahaan tanpa melihat jabatan dan kedudukan, hal ini disebabkan pencapaian tujuan perusahaan merupakan hasil kerja semua individu dalam perusahaan yang bersifat kolektif. Penelitian Kouzes (1993), menemukan bahwa kredibilitas yang tinggi akan mampu menghasilkan suatu komitmen dan hanya dengan komitmen yang tinggi, suatu perusahaan mampu menghasilkan bisnis yang baik.

Penelitian Tugiman (2000) mengenai pengaruh peran auditor interen serta faktor-faktor pendukungnya terhadap peningkatan pengendalian interen dan kinerja perusahaan, disimpulkan bahwa manajemen puncak sangat besar pengaruhnya terhadap pelaksanaan pengendalian intern. Selain itu, pelaksanaan pengendalian dapat efektif apabila terdapat komitmen diantara pihak-pihak yang terkait dalam perusahaan, baik sebagai individu maupun kelompok. Hal ini dimaksud agar tujuan perusahaan dapat dicapai dengan baik. Dengan komitmen dan pengendalian intern maka akan tercipta perusahaan yang efficiency, dan effectiveness untuk menciptakan good corporate governance dalam institusi, yang pada akhirnya akan meningkatkan kinerja perusahaan.

Berdasarkan definisi di atas, dapat disimpulkan bahwa corporate governance adalah suatu sistem yang mengatur bagaimana suatu perusahaan dijalankan (operasi) dan dikontrol atau sebagai tata kelola perusahaan yang baik. Sistem ini mengatur secara jelas dan tegas hak dan kewajiban pihak-pihak 
yang terkait dalam perusahaan. Penelitian Darmawati, dkk (2004), menunjukkan variabel corporate governance mempengaruhi kinerja perusahaan yang diukur dengan return on equity dan variabel kontrol secara statistik tidak mempengaruhi kinerja perusahaan yang diukur dengan return on equity. Klapper dan Love (2002) juga menyatakan bahwa terdapat hubungan positif antara corporate governance dengan kinerja keuangan yang diukur dengan return on asset

$\mathrm{H} 1$ = "terdapat pengaruh positif antara penerapan corporate governance dengan perspektif bisnis internal yang diukur dengan Employee Productivity“"

$\mathrm{H} 2$ = "terdapat pengaruh positif antara penerapan corporate governance dengan perspektif tumbuh dan belajar yang diukur dengan Employee Development Coverage"

\section{Metode Penelitian}

Sampel yang digunakan dalam penelitian ini adalah perusahaan-perusahaan yang terdaftar di Bursa Efek Indonesia (BEI), yang masuk dalam pemeringkatan penerapan corporate governance yang dilakukan oleh The Indonesian Institute for Corporate Governance (IICG) di tahun 2005 dan 2006. Dengan demikian, penetuan sampel dalam penelitian ini dilakukan dengan menggunakan metode purposive sampling, karena pemilihan sampel tersebut berkaitan dengan data corporate governance yang digunakan dalam penelitian ini adalah data yang diperoleh oleh IICG di tahun 2005 dan 2006.

Jenis data adalah data dokumenter. Data implementasi corporate governance menggunakan hasil survey IICG tahun 2005 dan 2006 yang berupa Corporate Governance Perception Index (CGPI). Sedangkan data lainnya yaitu laporan keuangan yang diperoleh dari Indonesian Capital Market Directory 2005 dan 2006.

Sumber data yang digunakan merupakan data sekunder karena diperoleh dari penelitian secara langsung melalui media perantara. Data sekunder berupa bukti, catatan atau laporan histories yang dipublkasikan atau yang tidak dipublikasikan.

Metode pengumpulan data menggunakan metode pooled data atau penggabungan data untuk memperoleh data mengenai Corporate Governance Perception Iindex (CGPI).

\subsection{Pengukuran Variabel}

\subsubsection{Variable Dependen}

Variabel dependen dalam penelitian ini adalah kinerja non keuangan perusahaan. Dalam penelitian ini kinerja non keuangan perusahaan diukur dengan menggunakan metode balanced scorecard sebagai ukuran kinerja keuangan dan non keuangan perusahaan.

a. Perspektif Proses Bisnis Internal (Process Business Internal Perspective)

Mistry \& Nandrams $(2002 ; 28)$

$$
\text { Employee Productivity }=\frac{\text { Income }}{\text { Number of Employees }}
$$

b. Perspektif Pembelajaran dan Pertumbuhan (Learning and Growth Perspective )

Mistry \& Nandrams $(2002 ; 28)$

$$
\text { Employee Development Coverage }=\frac{\text { Development Expenditures }}{\text { Number of Employees }}
$$

\subsubsection{Variabel independent}

\subsubsection{1. corporate governance}

Variabel independen dalam penelitian ini adalah corporate governance. Variabel ini diukur dengan menggunakan instrumen yang dikembangkan oleh IICG tahun 2005 dan 2006. Pada tahun tersebut IICG mengadakan survei tentang penerapan corporate governance pada perusahaan-perusahaan yang 
terdaftar di Bursa Efek Indonesia (BEI). Berdasarkan hasil survei, maka diperoleh Corporate Governance Perception index (CGPI). CGPI merupakan gabungan dari enam komponen yang diberi bobot. Enam komponen tersebut adalah: 1) komitmen terhadap corporate governance (15\%), 2) hak pemegang saham dan fungsi kepemilikan kunci (20\%), 3) perlakuan yang setara terhadap seluruh pemegang saham (15\%), 4) peran stakeholders dalam tata kelola perusahaan (15\%), 5) pengungkapan dan transparasi (15\%), dan 6) tanggung jawab dewan komisaris dan dewan direksi (20\%).

\subsubsection{Komposisi aktiva perusahaan.}

Hubungan antara proporsi aktiva tetap dengan corporate governance akan negatif (Klapper dan Love, 2002; Himmelberg, Hubbard dan Love 2000). Penelitian ini memasukkan komposisi aktiva sebagai variabel kontrol untuk memastikan bahwa hubungan corporate governance dengan kinerja tidak disebabkan oleh heterogenitas komposisi aktiva. Komposisi aktiva diukur dengan menggunakan rasio perputaran aktiva tetap (Klapper dan Love, 2002), dimana rasio ini mengukur seberapa efektif perusahaan menggunakan aktiva tetapnya.

$$
\text { Rasio perputaran aktiva tetap }=\frac{\text { Penjualan }}{\text { Aktiva tetap bersih }}
$$

\subsubsection{Kesempatan pertumbuhan (growth opportunity).}

Perusahaan yang memiliki kesempatan tumbuh yang tinggi pada umumnya membutuhkan dana eksternal untuk melakukan ekspansi, sehingga mendorong perusahaan untuk melakukan perbaikan dalam penerapan corporate gonernanve dalam rangka untuk menurunkan biaya modal (La Porta, dkk., 1999; Klapper dan Love, 2002). Jika nilai total revenue lebih tinggi untuk perusahaan yang memiliki kesempatan tumbuh tinggi, hal ini bisa disebabkan karena endogenitas pada variabel corporate governance dalam asosiasi antara corporate governance dengan kinerja. Dengan demikian, penelitian ini memasukkan variabel kesempatan pertumbuhan sebagai variabel kontrol. Kesempatan pertumbuhan diukur dengan menggunakan rata-rata pertumbuhan penjualan selama dua tahun terakhir (Klapper dan Love, 2002).

\subsection{Metode Analisis Data}

Metoda analisis data menggunakan analisis regresi linier berganda setelah memenuhi uji asumsi klasik. Dimana uji asumsi klasik menunjukkan variabel yang digunakan mempunyai hubungan yang signifikan dan terbebas dari multikolinieritas, autokorelasi dan heteroskedastisitas. Analisa regresi linier berganda ini untuk melihat apakah terdapat hubungan antara variabel corporate governance terhadap kinerja non keuangan perusahaan. Untuk memudahkan dalam menganalisis digunakan program SPSS, dengan signifikansi $(\alpha)$ sebesar $5 \%$ atau 0,05 .

$$
\begin{aligned}
& \mathrm{Y}_{1}=\beta \mathrm{o}+\beta 1 \mathrm{X} 1+\beta 2 \mathrm{X} 2+\beta 3 \mathrm{X} 3+\mathrm{e} \\
& \mathrm{Y}_{2}=\beta \mathrm{o}+\beta 1 \mathrm{X} 1+\beta 2 \mathrm{X} 2+\beta 3 \mathrm{X} 3+\mathrm{e}
\end{aligned}
$$

Dimana :

$\mathrm{Y}_{1} \quad$ : Kinerja (prespektif proses bisnis internal)

$\mathrm{Y}_{2} \quad$ : Kinerja (prespektif belajar dan tumbuh)

Bo : Konstanta

$\beta 1 \quad$ : Koefisien Regresi

X1 : CGPI

$\mathrm{X} 2$ : Komposisi Aktiva

X3 : Kesempatan Tumbuh

e : Error 


\section{Analisis Hasil Penelitian}

Tabel 1 menyatakan hasil perhitungan masing-masing variabel independen dan dependen, sampel penelitian adalah 34 perusahaan pada tahun 2005 dan 2006. Hasil penelitian pertama adalah menganalisa data dengan statistik deskriptif. Untuk variabel employee productivity mempunyai ratarata sebesar 112,6668 dimana setiap 1 orang karyawan perusahaan dapat menghasilkan laba bersih sebesar Rp112.666.800. Sedangkan variabel employee development coverage sebesar 3,4765 yang berarti Rp3.476.500 rata-rata biaya pendidikan dan pelatihan yang dikeluarkan perusahaan untuk setiap karyawan diperusahaan. Variabel independen corporate governance perception index sebesar 76,4738 merupakan rata-rata skor CGPI pada perusahaan pada tahun 2005 dan 2006 sebesar 76,4738. Variabel kontrol dengan komposisi aktiva perusahaan sebesar 14,2006 yang berarti penjualan perusahaan per Rp1.000.000 mempunyai rata-rata aktiva tetap bersih sebesar Rp14.200.600. Sedangkan variabel kesempatan pertumbuhan sebesar 5,6918, setelah di logaritmakan sehingga rata-rata pertumbuhan perusahaan selama dua tahun adalah Rp5.691.800.

\section{Uji Asumsi Klasik}

Menggunakan uji regresi linier berganda, mensyaratkan sebelumnya melakukan uji asumsi klasik, agar sampel yang diteliti tidak menyebabkan bias pada hasil penelitian. Uji asumsi klasik dilakukan dengan uji multikolinier, uji autokorelasi, dan uji heteroskedastisitas.

\subsubsection{Hasil Uji Multikolinier}

Uji multikolinieritas dilakukan menggunakan hasil perhitungan variance inflation factor (VIF) dari tiap variabel indepanden. Tabel 2 menyatakan nilai VIF untuk variabel CGPI sebesar 1,702. Variabel komposisi aktiva perusahaan memiliki nilai VIF sebesar 1,077. Dan variabel kesempatan pertumbuhan mempunyai nilai VIF sebesar 1,644. Dengan demikian nilai VIF dalam penelitian ini tidak lebih dari 10 menunjukkan tidak terdapat masalah multkolinier. Nilai VIF dari tiap-tiap variabel bisa dilihat pada tabel dibawah ini 2.

\subsubsection{Hasil Uji Autokorelasi}

Untuk mengetahui autokorelasi dalam suatu model regresi dilakukan melalui pengujian Dubin-Watson. Dengan variabel sebanyak $k=3$ buah dan sampel sebanyak $n=34$, karena nilai $D W$ pada $n=15$ sampai dengan 100 maka untuk $n=34$ dapat diperkirakan sedikit diatas $n=18$ dan dibawah $n=80$ yaitu $D W$ dalam selang 1,05 sampai dengan 1,70. Dari $d_{L}$ sebesar 1,05 dan nilai $d_{U}$ sebesar 1,70, maka dalam penelitian ini nilai d harus berada diantara 1,70 dan 2,3, agar tidak mengalami masalah autokorelasi. Dan hasil analisa untuk variabel dependen employee productivity nilai d sebesar 1,927 dan nilai d sebesar 2,141 untuk variabel dependen employee development coverage. Nilai d sebesar 1,743 dan 2,141 tidak mengalami masalah autokorelasi.

\subsubsection{Hasil Uji Heteroskedastisitas}

Dalam penelitian ini peneliti menggunakan uji Glejser dengan meregresikan variabel independen dengan nilai absolut dari residual. Dari hasil regresi tersebut jika terdapat koefisien yang signifikan pada level 0,05, maka terjadi heteroskedastisitas (Gujarati, 1995). Hasil regresi dengan uji Glejser ditunjukkan dalam tabel 3. Dari hasil regresi tersebut tidak terdapat variabel yang signifikan pada level 0,05. Dengan demikian model regresi tidak mengalami masalah heteroskedastisitas dan model regresi dapat dilanjutkan pada pengujian selanjutnya. 


\subsection{Diskusi}

Table 4 menunjukkan hasil pengujian hipotesis alternatif $\left(\mathrm{H}_{1}\right)$ diterima karena berdasarkan pengolahan data untuk p-value variabel corporate governance lebih kecil dari 0,05 . Hipotesis yang menyatakan bahwa corporate governance berpengaruh positif terhadap employee productivity secara statistik berpengaruh, sehingga Hipotesis $\mathrm{Nol}\left(\mathrm{H}_{0}\right)$ ditolak. Hasil pengujian pertama menunjukkan bahwa hanya variabel corporate governance yang secara statistik mempengaruhi employee productivity, sedangkan tidak satupun variabel kontrol yang secara statistik signifikan mempengaruhi employee productivity. Penelitian ini mendukung penelitian Darmawati, dkk (2004), dimana variabel corporate governance mempengaruhi kinerja perusahaan yang diukur dengan return on equity dan variabel kontrol secara statistik tidak mempengaruhi kinerja perusahaan yang diukur dengan return on equity. Klapper dan Love (2002) juga menyatakan bahwa terdapat hubungan positif antara corporate governance dengan kinerja keuangan yang diukur dengan return on asset. Dalam penelitian ini perusahaan besar dapat memiliki masalah keagenan yang lebih besar karena lebih sulit dimonitor sehingga membutuhkan corporate governance yang lebih baik lagi untuk memperkecil biaya yang dikeluarkan untuk masalah keagenan yang dapat berpengaruh pada perolehan laba perusahaan. Hasil ini sependapat dengan hasil yang ditemukan Gompers dkk (2003), dimana perusahaan yang lemah dalam penerapan corporate governance akan memperoleh laba yang lebih rendah. Sehingga dapat disimpulkan bahwa untuk meningkatkan kinerja perusahaan dibutuhkan mekanisme corporate governance yang lebih baik (Klapper dan Love, 2002).

Table 5 menunjukkan hasil regresi hipotesis alternatif $\left(\mathrm{H}_{2}\right)$ ditolak, hipotesis yang menyatakan bahwa corporate governance berpengaruh positif terhadap employee development coverage secara statistik tidak berpengaruh, sehingga Hipotesis $\mathrm{Nol}\left(\mathrm{H}_{0}\right)$ diterima, karena berdasarkan pengolahan data $p$ value CGPI lebih besar dari 0,05. Sedangkan variabel kontrol komposisi aktiva dan kesempatan tumbuh juga tidak signifikan atau berpengaruh terhadap employee development coverage. Ini menunjukkan bahwa perusahaan yang menerapkan good corporate governance dengan komposisi aktiva dan penjualan tertentu tidak mampu mempengaruhi terhadap besar kecilnya pengeluarkan biaya pendidikan dan pelatihan. Sehingga peningkatan terhadap penerapan corporate governance, aktiva, dan penjualan tidak mempengaruhi meningkat atau tidaknya biaya pendidikan dan pelatihan yang dikeluarkan perusahaan untuk peningkatan sumber daya manusia dalam perusahaan.

\section{Kesimpulan}

Penelitian ini bertujuan untuk mengetahui pengaruh penerapan good corporate governance yang diterapkan dalam suatu perusahaan dengan kinerja non keuangan perusahaan yang bersangkutan. Penelitian ini menggunakan ukuran yang dikembangkan oleh The Indonesian Institute for Corporate Governance (IICG) yang berupa Corporate Governance Perception Index (CGPI).

Hasil regresi linier berganda dengan variabel dependen employee productivity menunjukkan bahwa signifikansi variabel corporate governance menunjukkan hubungan yang signifikan terhadap variabel dependen employee productivity. Sehingga hipotesis alternatif $\left(\mathrm{H}_{1}\right)$ dierima, yaitu terdapat pengaruh positif antara corporate governance terhadap kinerja non keuangan perusahaan yang diukur dengan employee productivity.

Untuk signifikan variabel independen corporate governance, komposisi aktiva, dan kesempatan tumbuh perusahaan mempunyai $p$-value tidak signifikan. Dimana variabel corporate governance dan variabel kontrol tidak berpengaruh terhadap kinerja non keuangan yang diukur dengan employee development coverage. Ini berarti hipotesis alternatif $\left(\mathrm{H}_{2}\right)$ ditolak, sehingga corporate governance tidak berpengaruh positif terhadap kinerja non keuangan dengan alat ukur employee development coverage.

Keterbatasan pertama peneliti hanya menggunakan employee productivity dan employee development coverage sebagai ukuran kinerja non keuangan yang merupakan salah satu ukuran penilaian kinerja balanced scorecard untuk prespektif bisnis internal dan perspektif belajar dan tumbuh. Untuk penelitian selanjutnya diharapkan jika menggunakan kinerja non keuangan dengan metode balanced scorecard tetapi menggunakan ukuran yang lain dalam prespektifnya. Atau menggunakan alat ukur kinerja non keuangan lainnya seperti Total Quality Manajemen (TQM). Keterbatasan kedua adalah 
kurang pastinya keputusan pada autokorelasi, dimana nilai Durbin-Watson terletak antara $\mathrm{d}_{\mathrm{L}} \mathrm{dan}_{\mathrm{U}}$, yaitu daerah tanpa kesimpulan.

Bagi peneliti lain, untuk lebih dikaji ulang variabel-variabel lain yang tidak masuk dalam penelitian yang berkaitan dengan penerapan corporate governance dan kinerja non keuangan perusahaan. Disamping itu obyek penelitian perlu diperluas tidak hanya perusahaan yang mengikuti survei yang dilakukan IICG, tapi perusahaan-perusahaan yang melakukan self assessment dalam penerapan good corporate governance. Penelitian ini juga diharapkan mempunyai kontribusi bagi pihak regulator dalam hal gambaran tentang implementasi good corporate governance pada perusahaan publik di Indonesia serta faktor-faktor yang mempengaruhinya.

\section{DAFTAR PUSTAKA}

Bhagat, Sanjai dan Black, Bernard, 2002, The Non Correlation Between Board Independent and Long Term Firm Performance, Journal of Corporate Law, Winter 2002

Black, Bernard, 2001, The Corporate Governance Behivor and Market Value of Russian Firms, Stanford Law School, Social Science Research Network id-263014.

Campbell, D., Datar, S., Kulp, S. C., dan Narayanan, V. G, 2002, Using the Balanced Scorecard as a Control System for Monitoring and Revising corporate strategy, SSRN id-328880.

Darmawati, D, 2006, Pengaruh Karakteristik Perusahaan dan Faktor Regulasi Terhadap Kualitas Implementasi Corporate Governance, Universitas Trisakti, SNA 9 Padang 23-26 Agustus 2006.

Durnev, A dan Kim, E. Han, 2003, To Steal or Not To Steal : Firm Attributs, Legal Environment, and Valuation, SSRN id-391132.

Eisenhardt, Kathleen M, 1989, Agency Theory: An Assesment and Review, Academy of Management Review, Vol. 14. No. 1, pp. 57-74.

Fama, E dan Jensen, M, 1983, Separation of Ownership and Control, Journal of Law and Economics 26:301-325.

Gillan, S.L., Hartzell, J. C., dan Starks, L. T, 2003. Industries, Investment Opportunities, and Corporate GovernanceStructures. Working Paper.

Gompers, Paul.,Ishii, J.L., Metrick, A., 2003, Corporate Governance and Equity Prices, Journal of Economic 118 (1), February 2003.

Hansen, R Don and Mowen, Maryane M, 2004, Akuntansi Manajemen, Edisi 7, Penerbit Salemba Empat, Jakarta.

Ittner, Christopher D. dan Larcker, David, F. 1998 Innovations in Performance Measurement:Trends and Research Implications http:Ilwww.ssrn.com, 12 Februari 2004.

Jensen, M. C dan Meckling, W. H, 1976, Theory of The Firm : Managerial Behivior, Agency Cost and Ownership Structure, Journal of Financial Economics 3:305-360.

Johnson, Simon., Boone, P., Breach, A., dan Friedman. E, 2000. Corporate governance in Asian financial crisis. Journal of Financial Economics, 58, hal. 141-186.

Kaplan, R.S dan Norton, D.P, 1996, Balanced Scorcard, Edisi Terjemahan, Penerbit Erlangga, Jakarta.

Klapper, Leora F dan Love, Innesa, 2002, Corporate Governance, Investor Protection and Performance in Emerging Markets, Policy Reaserch Working Paper 2818. 
Kouzes, James.M,; Barr Z.Posner. 1993. Credibility, How Leaders Gains and Lose it, Why People Deman it. Jossey-Bases, Inc.

La Porta, R., Silanes, F. L. De., Shlifer, A, dan Vishny, R, 1999, Investor Protection : Origins, Consequences, Reform, NBER Working Paper 7428.

Malina, Mary A dan Selto, Frank H, 2001, An Empirical Study of The Balanced Scorecard, SSRN id278939.

Mistry, Jamshed dan Nandram, Balgobin, 2005, The Relevance ot the Balanced Scorecard in Assessing Firm Performance of eCommerce Companies, SSRN id-773105.

Rajan, Raghuram G dan Zingales, Luigi, 1998, Wich Capitalism? Lessons from The East Asian Crisis, Journal of Applied Corporate Finance.

Tugiman, Hiro, 2000, Pengaruh Peran Auditor Intern Serta Faktor-Faktor Pendukungnya Terhadap Peningkatan Pengendalian Intern dan Kinerja Perusahaan, Desertasi Program Doktor Universitas Padjadjaran, Bandung.

\section{LAMPIRAN}

Tabel 1 Statistik Dskriptif

\begin{tabular}{lrrrrr}
\hline & N & Minimum & Maximum & Mean & Std. Deviation \\
\hline CGPI & 34.00 & 55.06 & 89.27 & 76.47 & 8.71 \\
KOM_AKT & 34.00 & 0.49 & 81.88 & 14.20 & 20.50 \\
TUMBUH & 34.00 & 4.26 & 6.93 & 5.69 & 0.74 \\
EMP_PROD & 34.00 & 9.53 & 564.85 & 112.67 & 111.88 \\
EMP_DEV & 34.00 & 0.14 & 8.79 & 3.48 & 2.40
\end{tabular}

CGPI= Corporate Governance Perception Index,KOM_AKT=Komposisi Aktiva

TUMBUH=Kesempatan Tumbuh, EMP_PROD=Employ productivity

EMP_DEV=Employ Development Coverage

Tabel 2 Variance inflation factor

VIF $\quad$ VIF

Variabel Employ Productivity Employ Development Coverage

\begin{tabular}{lll}
\hline CGPI & 1,702 & 1,702 \\
Komposisi Aktiva Perus. & 1,077 & 1,077 \\
Kesempatan Pertumbuhan & 1,644 & 1,644 \\
\hline
\end{tabular}


Tabel 3 Hasil Uji Heterokedastisitas

\begin{tabular}{lrr}
\hline & \multicolumn{1}{c}{$\begin{array}{c}\text { P-Value } \\
\text { Employ Productivity }\end{array}$} & \multicolumn{2}{c}{$\begin{array}{c}\text { P-Value } \\
\text { Employ Developmen coverage }\end{array}$} \\
\hline (Constant) & 0.93 & 0.34 \\
CGPI & 0.10 & 0.20 \\
KOM_AKT & 0.07 & 0.36 \\
TUMBUH & 0.28 & 0.87 \\
\hline
\end{tabular}

Tabel 4 Hasil Regresi Employee Productivity

\begin{tabular}{lrrrr}
\hline \multicolumn{1}{c}{ Variabel } & \multicolumn{1}{c}{$\begin{array}{c}\text { Koef. } \\
\text { Regresi }\end{array}$} & Std. Eror & \multicolumn{1}{c}{ t } & P-Value \\
\hline CGPI $\left(\mathrm{X}_{1}\right)$ & 6,157 & 2,746 & 2,242 & 0,032 \\
Komposisi Aktiva Perus. $\left(\mathrm{X}_{2}\right)$ & $-1,477$ & 0,927 & $-1,593$ & 0,122 \\
Kesempatan Pertumbuhan $\left(\mathrm{X}_{3}\right)$ & $-15,054$ & 31,914 & $-0,472$ & 0,641 \\
Konstanta & $-251,490$ & & & \\
R & 0,442 & & & \\
Adjusted $R$ Square & 0,115 & & & \\
Sig.F & 0,085 & & & \\
N & 34 & & & \\
\hline
\end{tabular}

Tabel 5 Hasil Regresi Employee Development Coverage

\begin{tabular}{lrrrr}
\hline \multicolumn{1}{c}{ Variabel } & $\begin{array}{c}\text { Koef. } \\
\text { Regresi }\end{array}$ & Std. Eror & t & P-Value \\
\hline CGPI $\left(\mathrm{X}_{1}\right)$ & $-0,027$ & 0,057 & 0,491 & 0,627 \\
Komposisi Aktiva Perus. $\left(\mathrm{X}_{2}\right)$ & $-0,009$ & 0,019 & 0,504 & 0,618 \\
Kesempatan Pertumbuhan $\left(\mathrm{X}_{3}\right)$ & 1,326 & 0,660 & 2,009 & 0,054 \\
Konstanta & $-6,338$ & & & \\
R & 0,502 & & & \\
Adjusted $R$ Square & 0,177 & & & \\
Sig.F & 0,032 & & & \\
N & 34 & & & \\
\hline
\end{tabular}

